\title{
Well-Being and Personality of the Indegenous Community in Sungai Sayap, Terengganu
}

\author{
Khatijah Omar, Siti Nor Adawiyah Azzahra Kamaruddin, Md Khairul Azwan Md Razali, \\ Norhayati Ab Manaf, Nor Hayati Sa'at, Muhammad Abi Sofian Abdul Halim \& Hazman Samsudin
}

\begin{abstract}
Well-being is an essential element of life among people from all walks of life and the indigenous people communities are of no exception despite the fact that they still depend on nature and not entirely in the current state of modernity. This study will identify the level of well-being and the type of personality of Orang Asli community in Sungai Sayap, Terengganu. The data for this study were obtained from 20 respondents representing $65 \%$ of the Orang Asli community in Sungai Sayap. Descriptive and correlation analysis were performed using the Statistical Package for Social Science (SPSS Version 20). The study found that there is a significant relationship between well-being and personality among Indigenous people (Orang Asli) in Sungai Sayap, Terengganu. The findings of this study are expected to help the responsible parties to ensure that the well-being of the Indigenous people is taken care of and proper attention to the factors affecting the well-being of Indigenous people is given priority especially in planning social intervention efforts to further enhance the well-being of the Indigenous people in Terengganu, Malaysia.
\end{abstract}

Keywords : Indigenous People, Nature, Personality, Sustainability, Terengganu, Well-Being.

\section{INTRODUCTION}

Indigenous people are among the minority that forms the Malaysian community. The arrival of Indigenous people in Peninsular Malaysia began over 100 thousand years ago and they were believed to occupy this place before the arrival of other tribes or races. In most parts of the world, including Malaysia, indigenous people have always been synonymous with natural resources and have a unique cultural and tradition ever since. They are part of a society that has a unique language, traditional knowledge and beliefs.

Indigenous people in Malaysia are also known as Orang Asli.The Orang Asli community in Malaysia has been

Revised Manuscript Received on November 11, 2019.

* Correspondence Author

Khatijah Omar, Faculty of Business, Economics and Social Development, /and Institute of Tropical Biodiversity \& Sustainable Development, Universiti Malaysia Terengganu, Malaysia.Email: khatijah@umt.edu.my

Siti Nor Adawiyah Azzahra Kamaruddin, Faculty of Business, Economics and Social Development, University Malaysia Terengganu, Malaysia.

Md Khairul Azwan Md Razali, Institute of Tropical Biodiversity \& Sustainable Development, University Malaysia Terengganu, Malaysia.

Norhayati Ab Manaf, Institute of Tropical Biodiversity \& Sustainable Development, University Malaysia Terengganu, Malaysia.

Nor Hayati Sa'at, Institute of Tropical Biodiversity \& Sustainable Development, University Malaysia Terengganu, Malaysia.

Muhammad Abi Sofian Abdul Halim, Institute of Tropical Biodiversity \& Sustainable, University Malaysia Terengganu, Malaysia.

Hazman Samsudin, Institute of Tropical Biodiversity \& Sustainable Development, University Malaysia Terengganu, Malaysia. divided into three main groups namely Malay-Proto, Negrito and Senoi and from these three main groups there are 18 sub-ethnic groups. In fact, these Orang Asli have been classified as non-homogeneous groups because each sub-ethnicity has different languages and cultures and they consider themselves different from one another Interestingly, some of the Orang Asli in the northern part of Peninsular Malaysia speak Aslian languages that are found to be familiar with indigenous peoples in Burma, Thailand and Indo-China.

Although there are cultural differences among indigenous communities, they face common problems and struggle to recognize their identity, way of life and their rights. The community also adopts various ideas of development in their own way based on their traditional values, visions, needs and priorities. However, the term 'Indigenous' itself has given a negative connotation to this society.

Their living environment and their reliance on the forest resources have made them highly dependent on nature in ensuring their well-being. To date, some researchers have agreed that indigenous people rely very much on natural resources to sustain their livelihood. According to Lye [11], natural resources such as forests have a direct connection to this traditional community. Forests have become a major source of economic activity for them to obtain daily resources such as food and also source of their income. Nonetheless, the indigenous people are still able to continue their living in an increasingly developed world, but in their own way.

\section{LITERATURE REVIEW}

\section{A. Well-Being}

Well-being is a concept that undergoes a dynamic process. It gives people value to show the development or the changes in their life either towards better status or vice versa [1]. Yusof, Ali and Kamaruddin [24] stated that the concept of well-being in life is multi-dimensional, but it is often determined by income levels. However, measurements made through income determination will produce questionable accuracy to determine the true and actual level of well-being. Manaf, Abdullah and Saputra [12] agreed that well-being is a broad concept and contains many aspects of life including economic, psychological and social. Earlier studies by Norizan Abdul Ghani [20] have stated that the concept of well-being has been divided 
into two categories, objective and subjective. Objective well-being means the living needs of the individual and can be seen externally through the aspects such as income, education, health and accommodation while the subjective category is assessed through the satisfaction of life achieved by the individual such as happiness and gratitude throughout life. Therefore, subjective well-being is more accurately used as a measure of human well-being [1] and it is also at the highest level of satisfaction and well-being [12].

The well-being of life is one of the major national development agendas given priority by some developed countries [1]. Malaysia is also one of the few countries that focus on the well-being of life as part of the national development agenda. Since its independence, the Malaysian government has always strived to improve the level of well-being of its society regardless of race and religion. Efforts made by the government to develop the Malaysian Welfare Index are aimed at improving the level of well-being encompassing two sub-sectors, namely economic and social well-being [23].

According to Ali [5] there are two forms of development programs that focus on the community to improve the level of well-being, namely economic development programs and social development programs. The economic development program emphasizes on land use activities for commercial crops and provides agricultural subsidies and trainings aimed at improving the community socioeconomic status. For social development programs, the focus is on the provision of infrastructure, housing, health service and education.

For the indigenous people who live mostly in remote areas, there is still a setback in the development process in their areas. Seow, Mohamed, Jamiran, Zainal Abidin and Mohd Sam [22] stated that various policies and funds have been allocated by the government for the development and well-being of the indigenous people. However, the well-being of the Orang Asli community is still at a low level compared to other communities, although various development programs have been implemented involving that community [14].

According to Abdullah [3] difficult-to-change attitudes, low self-esteem, unwillingness to take risk and high caution in their work-life practices are among the factors that hinder their involvement in the development programs planned by the government. In addition, the study by Manaf, Abdullah, Abdul Halim and Omar [14] has also confirmed that participation in social development programs among Orang Asli is low due to the fact that they are still adopting or practicing traditional ways of life and being reluctant to mingle around with people from other races or from outside. That attitude may also be caused by their poor social skills, skepticism, and low education levels and lacking of self-confidence [13].

Most of the development programs, whether economic development programs or social development programs, aim to improve Orang Asli's livelihood. According to Amir Zal [6] the development programs for Orang Asli implemented by the government agencies have brought some positive

impacts to Orang Asli community. They have started to accept some changes in their everyday life, for examples, living in much proper dwellings, consuming cleaner water supply, enjoying electricity and living in a much better life. However, this new way of life has also threatened the value of their traditional knowledge, skills and work-life practices that they inherit from their ancestors before. Manaf et al. [13] also voiced out that the process of modernization among indigenous people or Orang Asli can also pose a threat to their future and their well-being.

Studies by Jamiran, Seow and Mohamed [10] on the transformation of Orang Asli's socioeconomic development have also found that development can have a negative impact on their identity and that positive change can only occur over quite some time. The intended change, however, can be speed up if the indigenous people or Orang Asli are willing to participate in the development programs provided for them [22]. Participation from Orang Asli in development programs designed and implemented for them is very important as it can improve their well-being especially for the long run.

Previous studies have shown that the well-being of the indigenous people is still low and lagging behind in most aspects including economic and social development [15],[10]. In addition, Manaf et al. [12] and Manaf et al. [14] also stated that the well-being of the indigenous people is still at unsatisfactory level because of the high poverty rate and low education level despite the implementation of various development programs.

\section{B. Personality}

Personality is one of the dynamic aspects that forms the basis of the individual's thoughts, feelings and behaviors [7]. In general, the indigenous people still practice a variety of heritage such as cultural customs, beliefs, health practices and unique values. This society has a harmonious relationship with people and their natural environment. This harmonious relationship has been affecting not only their socio-economic status but also their personality. According to Mee and Ibrahim [17], the life of the indigenous people is indeed influenced by two main aspects: the environment and the practice of their ancestors. Majority of indigenous people are very reserved and introvert. This was admitted by many researchers who committed themselves going down the field to get closer to this community. It was a bit difficult to get closer to them because they were very shy when meeting the outsiders. An appropriate approach is necessary to get them interested in communicating with outsiders.

In the eyes of the world, indigenous people are the society that forms their philosophy of life based on the beliefs that exist in their society [19]. According to Abdul Rahman [2], philosophy, culture, beliefs and ethics will influence their behavior and the way they interact with their environment. The philosophies of life held by this society, which are based on myths, beliefs, taboo, customs and so forth, 
will also characterize their personality and later will also influence their actions.

Indigenous peoples' personalities are also greatly influenced by the environmental and physical conditions of their surroundings. Forests, mountains and hills have their own meanings to Orang Asli. The natural environment has also influenced their taboos, beliefs and personality [21]. For example, according to Abdul Rahman [2] Semai people are not allowed to kill animals or else the perpetrator will be punished by supernatural [18]. It is clear that the indigenous people or Orang Asli have the personality that respects the nature and supports environmental sustainability.

\section{METHODOLOGY}

Data for this study were collected from Orang Asli in Sungai Sayap, Terengganu, Malaysia. This study was conducted in December 2018. Questionnaire-based study was applied to obtain information from respondents. The instruments for this study were adapted from Keyes [25] and Strumfer, Hardy, Villiers and Rigby [26]. The well-being was measured using an instrument consisting of 15 items and 18 items were used to measure personality among Orang Asli in Sungai Sayap. Some of the items for measuring well-being are like 'you feel like you have a good relationship with your friends, you feel like life has purpose and meaning and so on'. Items for personality are measured through five dimensions which are conscientiousness, extraversion, and openness to experience, agreeableness and neuroticism. Some of the questions are like 'I'm always considerate type of people, I'm worried when something bad happens, I'm a helpful and selfless person, and so on'. The total of respondents participated in this study was 20 out of 31 Orang Asli from 10 families who live in this village. The respondents represented $65 \%$ of the population. The data collection session for this study was conducted using an intermediary from the Orang Asli community to translate words that were not understood by a few respondents involved in this study. The data obtained were analyzed using descriptive and correlation analysis.

\section{FINDINGS}

Table I shows that the Orang Asli respondents in this study were 80 percent female and 20 percent male. The age of the respondents in this study were between 15 and 62 years old. The majority of them were from the Batek tribe (95\%) and Malay (5\%). 60 percent of the respondents were married, while 30 percent were single. 10 percent of the respondents were widowers or single mothers. $55 \%$ of the respondents who involved in this study did not complete their primary school education and their jobs were mostly farming or fishing. In terms of income, all respondents earned less than RM999 per month.

Table I Descriptive Analysis (Respondent Profile)

\begin{tabular}{lccc}
\hline $\begin{array}{l}\text { Demographic } \\
\text { Characteristics }\end{array}$ & $\begin{array}{c}\text { Frequency } \\
(\mathrm{n}=20)\end{array}$ & Percentage \\
\hline Gender & Men & 4 & 20 \\
\hline
\end{tabular}
range of 1 - and +1 .

Table II shows the results of the normality test. The normality test was conducted to determine whether the data used in the study was normal. This study used descriptive analysis (Skewness and Kurtosis) to determine the normality of the data. According to Chua [8] the distribution of data would be considered as normal if Skewness and Kurtosis values were in the range of -1 and +1 . Therefore, the data in this study are normally distributed because they are in the

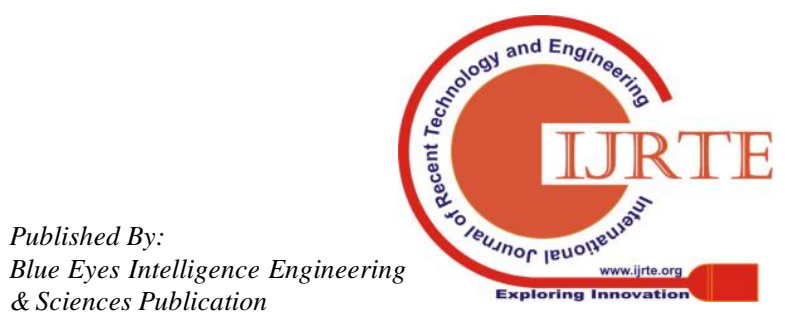


Table II Descriptive Statistics (Skewness and Kurtosis)

\begin{tabular}{|c|c|c|c|c|c|c|c|}
\hline \multirow[t]{2}{*}{ Variables } & \multirow{2}{*}{$\begin{array}{l}\text { Mean } \\
\text { Statis } \\
\text { tic }\end{array}$} & \multirow{2}{*}{$\begin{array}{l}\text { Std. } \\
\text { Dev. } \\
\text { Statisti } \\
\text { c }\end{array}$} & \multicolumn{3}{|c|}{ Skewness } & \multicolumn{2}{|c|}{ Kurtosis } \\
\hline & & & $\begin{array}{l}\text { Stati } \\
\text { stic }\end{array}$ & $\begin{array}{l}\text { Std } \\
\text { Erro }\end{array}$ & & $\begin{array}{l}\text { Stat } \\
\text { isti } \\
\text { c }\end{array}$ & $\begin{array}{l}\text { Std. } \\
\text { Erro } \\
\mathrm{r}\end{array}$ \\
\hline $\begin{array}{l}\text { Well-Bei } \\
\text { ng }\end{array}$ & 4.105 & .66291 & .038 & $\begin{array}{l}.51 \\
2\end{array}$ & $\begin{array}{l}-1.1 \\
2\end{array}$ & & 992 \\
\hline $\begin{array}{l}\text { Well-Bei } \\
\mathrm{ng} \\
\text { (Percepti } \\
\text { on of } \\
\text { Life) }\end{array}$ & 4.920 & $\begin{array}{l}1.2024 \\
5\end{array}$ & $\begin{array}{l}-.31 \\
0\end{array}$ & .512 & & $\begin{array}{l}-1.0 \\
05\end{array}$ & .992 \\
\hline $\begin{array}{l}\text { Personali } \\
\text { ty }\end{array}$ & 4.866 & .55538 & $\begin{array}{l}1.02 \\
1\end{array}$ & .512 & & $\begin{array}{l}1.0 \\
84\end{array}$ & .992 \\
\hline
\end{tabular}

Table II above also shows the level of well-being among the Orang Asli community in Sungai Sayap, Terengganu with the mean value of 4.1050 and standard deviation of 0.66291. Furthermore, the mean value for well-being (perception of life) was 4.9200 with standard deviation of 1.20245. Meanwhile, personality gained mean value of 4.8667 with standard deviation 0.55538 . All of the above values exceed the average mean value level of 3.5.

Table III shows the reliability values (Cronbach's Alpha) for each of the variables used in this study. Cronbach's Alpha for the overall Well-Being variables is 0.738, Well-Being (Life Perceptions) 0.767 and Personality 0.701. Devellis [9] stated that Cronbach's alpha value that is above 0.70 is respectable, 0.80 is good and 0.90 is very good.

Table III Reliability Analysis (Cronbach'sAlpha)

\begin{tabular}{lc}
\hline Variable & CA \\
\hline Well-Being (General Feeling) & 0.738 \\
Well-Being (Perception of Life) & 0.767 \\
Personality & 0.701
\end{tabular}

Table IV shows that there is a significant relationship between well-being with personality among Orang Asli in Sungai Sayap $(r=0.692$ and sig $=0.001)$. The strength of the relationship is at the moderate level.

Table IV Correlation Analysis

\begin{tabular}{llll}
\hline Variable & & $\begin{array}{l}\text { Well-Be } \\
\text { ing }\end{array}$ & Personalities \\
\hline Well-Being & $\begin{array}{l}\text { Pearson } \\
\text { Correlation }\end{array}$ & 1 & $.692^{* *}$ \\
& Sig. (2-tailed) & & .001 \\
& $\mathrm{~N}$ & 20 & 20 \\
Personality & Pearson & $.692^{* *}$ & 1 \\
& Correlation & & \\
& Sig. (2-tailed) & .001 & \\
& N & 20 & 20
\end{tabular}

**. Significant correlation at level 0.01 (2-tailed).

\section{DISCUSSION}

In general, the well-being, perception towards life and personality among indigenous people (Orang Asli community) in Sungai Sayap, Terengganu, is above average. This shows that the level of well-being of the Orang Asli under study is satisfactory while their personality is still intact with those who adhere to one another. This is further reinforced by the findings of the previous study showing that there is a significant relationship between well-being and personality. In this study, the well-being of Orang Asli community in Sungai Sayap is at a satisfactory level and their personality is also good. Such personality will create a harmonious life among the members in this community. In addition, this community also practices a caring attitude. They care not only for the members in their community but also for the natural environment that they are living in. This was supported by Abdul Rahman [2] who stated that Orang Asli people really care about their forest and what is in the forest. They disallow the killing of animals and the destruction of plants and environment. They believe that if they do so, they will be punished by the supernatural [18].

\section{CONCLUSION}

The results show that the Orang Asli people in Kampung Sungai Sayap have their own uniqueness in terms of their well-being and their personality. Their personality actually is said to be shaped by nature and the communities that they are living in as well as their close relationships with one another. The value of such living has united them together.

Although their outside world enjoys the current state of modernity, indigenous or Orang Asli people generally feel comfortable with their level of well-being even though their outer world conmonbich'sindlphlaeir well-being as at a low level. This impliesgthat the measure of the well-being of their life is differenffrom the measure of the well-being of other people who are said to be in the stream of modernity. Orang Asli continue to enjoy life in their own way and continue to wisely rely on nature for their sustainable livelihood.

\section{ACKNOWLEDGEMENTS}

The authors would like to thank Universiti Malaysia Terengganu for financial support (KTAG Grant) and Institute Tropical Biodiversity \& Sustainable Development and its staff for their cooperation and full support.

\section{REFERENCES}

1. Ab Ghani, M. H., Paim, L., \& Sabri, M. F. (2013). Tahap Kepuasan ke atas Pendapatan, Perbelanjaan, Simpanan dan Pemilikan Harta Isi Rumah dalam Kalangan Penjawat Awam di Putrajaya, 40, 81-102.

2. Abdul Rahman, H. (2018). World View Masyarakat Orang Asli dan Pelestarian Alam Sekitar. Seminar Antarabangsa Arkeologi, Sejarah, Bahasa dan Budaya di Alam Melayu (ASBAM5), 28-29 Julai 2018. Lombok, Indonesia.67-74. ISBN 978-602-51125-3-9.

3. Abdullah, R. (2014). Orang Asli Pembangunan dan Transformasi. Kuala Terengganu: Universiti Sultan Zainal Abidin. 
4. Abu Samah, A. (2006). Participation and Quality of Life: A Study on the People's Empowerment in a Malay Village Community. Pertanika Journal of Social Sciences \& Humanities, 14(1), 11-25.

5. Ali, Z. A. (2008). Peranan Jabatan Hal Ehwal Orang Asli (JHEOA) dalam Pembangunan Masyarakat Orang Asli. In: Ma'rof Redzuan dan Sarjit S. Gill (eds) Orang Asli: Isu, Transfromasi dan Cabaran. Universiti Putra Malaysia, Serdang.

6. Amir Zal, W. A. (2013). Pembentukan modal insan Orang Asli Darat dan Laut di Malaysia. Geografia: Malaysian Journal of Society and Space, 9(4), 1-14.

7. Bhullar, N., \& Wall, H. (2018). Personality and Positive Psychology, (January).

8. Chua YP (2006). Asas Statistik Penyelidikan. Mcgraw-Hill, Selangor, Malaysia.

9. Devellis RF (2016). Scale Development Theory and Applications. SAGE Publications, Thousand Oaks, USA.

10. Jamiran, M. N., Seow, T. W., \& Mohamed, M. (2013). Sosioekonom Masyarakat Orang Asli : Kajian Kes Di Kampung Peta, Johor Simposium Kebudayaan Indonesia-Malaysia, 12-14 November 2013, Universitas Padjadjaran, Bandung, Indonesia.

11. Lye TP (2002) The Significance of Forest to the Emergence of Batek Knowledge in Pahang, Malaysia. Journal Southeast Asian Studies 40 (1)

12. Manaf, N. A., Abdullah, R., \& Saputra, J. (2016). Paper presented at the Universiti Malaysia Terengganu International Annual Symposium on Sustainability Science and Management (2016: Kuala Terengganu) 13. (2016).

13. Manaf, N.A., Abdullah, R., Omar, K., Halim, M.A.S.A., Simin, M.H.A., \& Hashim, S.S. (2019). Local Community Partnership in Social Development Program: National Community Case Study in Terengganu. International Journal of Recent Technology and Engineering, 7 (6S5), $1541-1546$

14. Manaf, N. A., Abdullah, R., Abdul Halim, M. A., \& Omar, K. (2018) USA PASSION DEVELOPMENT CONFERENCE PROCEEDING EISBN: 978-967-2273-02-8 International Conference of Management, Business \& Social Sciences Impact (ICMBSSI 2018). (2018), (Icmbssi), $0-7$.

15. Marzuki, M. (2013). Aksesibiliti Geografi Untuk Trip Sekolah di Kalangan Masyarakat Orang Asli: Kajian di Majlis Daerah Tapah. Tesis, Universiti Pendidikan Sultan Idris.

16. McGrath, N., Armstrong, R., \& Marinova, D. (2006). Reframing Poverty of Indigenous Australians.

17. Mee. S. dan Ibrahim, Y. 2008. Pembandaran dan Penempatan Semula Komuniti Orang Asli. Dlm. Marof Redzuan dan Sarjit S. Gill (Pnyt.) Orang Asli: Isu, Transformasi dan Cabaran. Serdang: Penerbit Universiti Putra Malaysia.

18. Mohammad Aslam, M. M., \& Abdullah, S. (2004). Pembentukan Nilai Murni Masyarakat Semai Melalui Konsep Pandang Dunia (World View): Satu Analisis Awal. Seminar Antarabangsa Nilai dalam Komuniti Pasca Modenisme (SIVIC 2004), 4-6 September 2004, Hotel City Bayview, Langkawi, Kedah.

19. Nik Hussain, N. H. (1999). Pembentukan Nilai-Nilai Murni Masyarakat Orang Asli Kelantan Melalui Konsep Tarian Sewing. Diterima daripada http://eprints.usm.my/38686/1/Pembentukan_Nilai_nilai_murni_masya rakat_orang_Kelantan_melalui_Tarian_Sewang.pdf.

20. Norizan Abdul Ghani. (2003). Kualiti Hidup Penduduk Pulau Negeri Terengganu: Satu Kajian Di Pulau Redang dan Pulau Perhentian. PHD Tesis.

21. Omar,K., Halim, M.A.S.A, \& Samsudin, H. (2018). Career Transformation among Orang Asli: Are They Ready? Indian Journal of Public Health Research and Development, 9 (12), 2615-2619

22. Seow, T. W., Mohamed, M., Jamiran, M. N., Zainal Abidin, Z. Z., \& Mohd Sam, S. A. (2003). Pembangunan Sosioekonomi Komuniti Orang Asli Di Malaysia. Persidangan Kebangsaan Geografi \& Alam Sekitar Kali Ke 4.

http://eprints.uthm.edu.my/3997/1/PEMBANGUNAN_SOSIOEKONOMI_ KOMUNITI_ORANG ASLI.pdf.

23. Unit Perancang Ekonomi Jabatan Perdana Menteri (UPE-JPM). (2013). Laporan Kesejahteraan Rakyat Malaysia 2013 (Vol. 130).

24. Yusof, A.M., Ali. J., \& Kamaruddin, R. (2014). Kesejahteraan Hidup Subjektif: Pengaruh Elemen Ekonomi dan Bukan Ekonomi. Prosiding PERKEM Ke-9, 9, 719-727.

25. Keyes, C.L.M. (2005). Mental Illness and/ or Mental Health? Investigating Axioms of the Complete State Model of Health. Journal of Consulting and Clinical Psychology. Vol. 73(3), 539-548.

26. Strumfer, D.J.W., Hardy, A., Villiers, J.S.D., \& Rigby, S. (2009). Organisationally Relevant Variables and Keyes's Mental Health Continuum Scale: An Exploratory Study. SA Journal of Industrial Psychology, 35,165-171. 